\title{
Reconstructing agency by shifting perspective in trauma narrative
}

\author{
Eszter Berán ${ }^{1}$ \\ Pázmány Péter Catholic University \\ Zsolt Unoka $^{2}$ \\ Semmelweis University
}

\begin{abstract}
In the treatment of sexual abuse victims reconstructing the abuse narrative from fragmented memories and gaining back a healthy sense of agency are major objectives of therapeutic interventions. Our analysis of the psychotherapy process in case of a sexual abuse victim analyzes in-session interaction in terms of joint construction of narrative by client and therapist in psychodynamic psychotherapy, focusing on the immediate effects of the therapist's single interventions on the reconstruction of the client's self-narratives. We discourse analyze the interaction of one audio recorded therapy session. We examine narrative perspective (NP) in the text using our discourse-based model of perspective. Our analysis reveals how - in the course of reconstructing the abuse narrative with the help of her therapist - a reconstruction of agency and patiency takes place through shifting the client's NP. The client's perspective of her own role as agent goes through gradual shifts as the interaction progresses. The therapist has a crucial role in the reconstruction process by influencing the client's perspective shifting behavior through shifting NP in her own interventions. Implications for psychotherapy research and clinical practice are discussed
\end{abstract}

\section{Introduction}

Dissociated or confused memories, loss of control and lacking a sense of agency has been considered important characteristics of trauma narratives of sexual abuse victims (O'Kearney \& Perrott, 2006). Reconstructing an abuse narrative from memories of flashbulbs or dissociated fragments (Allen, 2001), and regaining a healthy sense of agency are major objectives in therapeutic interventions aiming at recovering patients from psychopathological complications arising as a result of sexual violence (e.g., PTSD, depression, dissociation, etc.). The purpose of our study is to analyze client-therapist interaction by studying the joint construction of trauma narratives taking place at a psychodynamic therapy session. The main question we want to answer in our particular analysis is how the client's agency and patiency (i.e., a sense of powerlessness and

1 Eszter Berán, Department of Developmental and Clinical Child Psychology, Pázmány Péter Catholic University, e-mail: beran.eszter@btk.ppke.hu

2 Zsolt Unoka, Department of Psychiatry and Psychotheray, Semmelweis University, e-mail: unoka.zsolt@med.semmelweis-univ.hu 
passivity) is reconstructed in the course of narrative interaction at the therapy session, and how the therapist's interventions influence this process.

By reconstruction process we refer to the gradual transforming of the original narrative (a dream) in terms of its emotional relevance, reorganizing the memory episode it contains, and creating a new narrative, which can be reintegrated into the autobiographical knowledge system (Habermas, 2012; Lane, Ryan, Nadel, \& Greenberg, 2014). In the narrative reconstruction process we focus on the shifting of narrative perspective (NP) of the talkers. The concept of NP (Genette \& Sheridan, 1982; Uspenskij, 1973) refers to the narrator's point of view while telling a narrative, from which viewpoint events and characters are presented to the listener. In our analysis of in-session interaction with a female client who has suffered a trauma of repeated sexual and emotional abuse we concentrate on the shifting perspective of agency and patiency in the narrative. We show how a reconstruction of the client's sense of agency takes place through a series of shifts in her NP. However other aspects of NP such as shifting between different strategies of remembering (Conway, Singer, \& Tagini, 2004) are also shown to have an important role in reconstructing the client's self-narrative. Importantly, our analysis also reveals how, and through which interventions the therapist helps the client to recover and reconstruct her abuse experience. We suggest that this is accomplished by the therapist's influencing the client's perspective shifts through shifting NP in her own interventions. Thus, by a detailed analysis of the interactive perspective shifting behavior of the talkers, we are able to study the role of individual therapeutic interventions in helping the client to accommodate a new point of view.

\section{The Problem of Agency and Patiency in the Psychotherapy of Abuse Victims}

Clinical consequences of sexual abuse and trauma include the loss of a healthy sense of agency. Loosing agency can be traced in post-traumatic symptoms such as the inability to integrate conscious experiences in dissociation, and to control retrieval inhibition. This leads to intrusive and repetitive recall of the trauma memories (Conway, Harries, Noyes, Racsma'ny, \& Frankish, 2000), transient amnesia regarding the traumatic event, as well as intensive, uncontrollable emotions, psycho-somatic symptoms, and nightmares (American Psychiatric Association \& American Psychiatric Association.Task Force on DSM-IV, 1994). According to Bromberg (2003) as a result of the traumatic event biochemical, physical, perceptual, cognitive and emotional processes may become dysfunctional. Memory of the traumatic event may be dissociated (Van der Kolk, 1996; Bromberg, 1994), and as a result, conscious retrieval may not be possible. Hence, a hiatus may be created in the abused person's self-narratives reducing coherence of the self.

A common goal of debriefing, cognitive behavioral and psychodynamic therapies with sexual abuse trauma cases is the reconstruction of a healthy sense of agency while reconstructing the narrative of traumatic experience (Kaminer, 2006). The reconstruction process taking place in therapy helps the client in the emotional re-experiencing of events in a safe and supporting environment while creating a linguistic representation of experiences with the aim to integrate sensory-perceptual episodic memory of the traumatic event with the autobiographic knowledge-system of the self (Allen, 2001; Beaudoin, 2005; Conway, 2001; Kaminer, 2006). Judith Herman (1987) from a psychoanalytic point of view considers it important for the client to recognize the trauma narrative as her/his own and recreate the continuity with earlier events of the life story. 
Keskien (2004) makes another important point shading a different light on the problem of agency in the case of sexual abuse victims. She argues that one must be careful in assuming such clients to be responsible actors in their abuse narrative, for example, when responsibility on the part of the victim is assumed for the continuation of intimate violence, or, for the occurrence of sexual assault. This is still the case in various social or cultural contexts, where stigmatization of the victim often implies responsibility on her part. While therapists think it critical for clients to gain a sense of self-agency: to learn to take action, maintain their rights, gain autonomy and independence in the abusive situation, it is also important to help them to a relief from guilt, in case trauma victims feel as solely responsible for the consequence of their experiences. Therefore, reframing, re-narrating and reconstructing trauma narratives may revolve around the problem of accepting powerlessness and patiency as much as around gaining a sense of agency. Reconstructing both the client's agency and patiency and that of other actors in the narrative is part of the reconstruction process that takes place in psychotherapy.

\section{Agency and Patiency in Narrative}

In narratives, the problem of agency and patiency is tied to the question of intentional action (Karlsson, 2002). Agency concerns whether an event in the story comes about as a result of a character's intentional behavior, or as a consequence of chance, natural law, or some other process. Traditionally, narrative agents are considered to be human, or humanized beings, who perform actions and initiate processes (Prince, 2003; Bremond, 1973). Patiency, in contrast, concerns the passive suffering of consequences of others' actions or events of the narrative. Patients are affected by processes initiated by agents, and their situation is modified by consequences of events that happen to them, but are not initiated by them.

Empirical study of agency and patiency in self-narrative from a psychological point of view has been based on differing conceptualizations by authors such as McAdams (Adler, Skalina, \& McAdams, 2008), Schafer (1976), and Habermas (2006). McAdams argued that a sense of agency is expressed as stories of self-protection, self-assertion, and selfexpansion, with the primary motivation to master or gain control over the self or the outside world (McAdams, 2001). He studied themes of agency in self-narratives, however did not consider expression of patiency in narratives at all. Schafer (1976) distinguished between the narrator/character's role in the story as an active agent or passive sufferer of events and consequences. According to Schafer when the narrator portrays herself as a passive sufferer or "patient" hiding her motivations even from herself, she is at the same time, avoiding her own responsibility in outcomes and events. Habermas (2006) building on Schafer's idea argues that taking (moral) responsibility for ones action is expressed through various aspects of NP. Thus, in order to express moral responsibility of actors it is not sufficient for the narrator to be represented as an actor in the story; rather, it is necessary to use mental verbs of wanting and deciding.

In contrast to narrative accounts relating agency and intentionality, a more general view is offered by Jackendoff's (1992) view of agency based on his cognitive-semantics theory, which may be applied to any type of text including narratives. According to this view, agency is interpreted in a broad sense, and hence not only intentional actors (i.e., persons) may be regarded as agents, but also those inanimate objects or processes, which can fill the place of an argument in the cause function (Jackendoff, 1992). For examples, in statements like "the stream of water developed a floodplain" agency is attributed to 
water (inanimate object), causing through a physical process, whereas in a statement like "my stomach digests the food" agency is attributed to a body part (part of the self) as causing the physiological process of digestion. Expanding Jackendoff's view to patiency, we interpret it as any living or inanimate object filling the place of an argument in the cause function as well; however, referring to who or what is being subjected to a causeevent, or undergoing state-alteration. The implication of these distinctions to psychological explanations of intentionality in narratives is that it accounts for important aspects of the narrator's representation of different types of agents and patients in the story: whether the agent or patient mentioned is identical with the narrator, or not, a living person, or inanimate object/process - which have been shown to be relevant concerning sense of agency and moral responsibility of actors in narrative accounts (Habermas, 2006; Schafer, 1976).

In order to systematically assess agency and patiency in therapeutic discourse we use Jackendoff's concept of agency as a basis of our definition. We differentiate agency types in narrative based on potential agents: a) self of the narrator, b) part of the narrator's self (e.g., body part of the narrator), c) another living person, or d) an inanimate object, or process - which, importantly, may express various "degrees" of responsibility on the part of the narrator although we do not consider these categories to constitute an ordinal scale. We analyze patiency in an identical way to agency, distinguishing the same types of patients as the sufferers of outcomes and events in the narrative.

\section{Constructing Self-Narratives in Psychotherapy while Shifting Perspective}

In the therapeutic setting the client's self-narratives are jointly constructed by reconstructing and negotiating stories, identities, and agencies with the therapist (Beran \& Unoka, 2005; Habermas, 2006; Ochberg, 1994; Schafer, 1976; Labov \& Fanshel, 1997). In this joint construction process the patient and therapist negotiate the meaning of narratives: they reinterpret and modify them. Old stories are reconstructed and transformed by new meanings resulting in transformation of the narrative (Beran \& Unoka, 2005). During this process, shifts in the talkers' perspective also occur.

The concept of NP, as mentioned above, is used to define the narrator's position with respect to the story plane, the time and place of its actions, actors, and characters (Genette \& Sheridan, 1982; Uspenskij, 1973). In self-narratives, told in first person singular, the events are seen from the point of view of the main protagonist. When the client recollects a childhood memory or narrates a recent event to the therapist, she presents, and represents the events by showing them from a specific angle, or point of view. She recounts events through the lenses of his/her current self, influenced by unconscious or conscious factors such as current emotional states, and those at the time of events, his/her attitudes, desires, intentions, etc. Such influential factors determine the narrator's/client's use of linguistic structures, and the organization of the narration itself (Beran, 2005; Berán, 2011; Zubin, 1995). As it has been argued previously (Beran \& Unoka, 2005) there is an interconnection between the speaker's NP, and the specific memories that she/he has access to, come up in his/her mind, and become verbalized. As a consequence, shifting of NP plays an elemental, formative role in the continuous changing, reshaping and reconstructing of self-narratives that takes place in therapeutic treatment. During therapeutic interaction NP of the speakers is continuously shifted, and by tracking these continuous shifts we can characterize the construction process of the narrative self. 
Our study illustrates that patient's and therapist's perspective shifts are not independent from each other. Rather, speakers influence each-others perspective shifts as interaction progresses. We argue that coordination or alignment of NPP between the speakers occurs similarly to coordination or alignment of other discourse communication phenomena, such as bodily posture, use of certain grammatical structures, or vocabulary (Garrod \& Pickering, 2009).

Since perspective used by one speaker draws attention of the other speaker to a specific aspects of the narrative (Nelson \& Fivush, 2004), NP used by one speaker influences the NP of the other speaker in his/her consecutive utterances. We refer to this process as coordination of perspectives or mutual regulation of the speakers' NP shifting behavior. Mutual regulation of NP allows the therapist to influence the client's shifting behavior. Thus, consequences of individual therapeutic interventions as affecting the client's shifts can be traced throughout the narrative construction process. Studying interrelated shifting behavior of the talkers is useful for an "online" description and detailed understanding of the transformation of the client's narrative.

\section{A Discourse-Based Model of Perspective}

We defined NP using four component aspects of perspective which could be assessed by discourse based variables applied on our unit of analysis that we used for segmentation of the speech flow: intonation unit (Chafe, 1994; Clark, 1996). (For a more detailed description of the linguistic variables see the "Methods" section below.)

1) Physical aspect: refers to the spatial and temporal axis of the narrator/character's point of view, providing spatial and temporal "coordinates" of the narrator's position (Genette \& Sheridan, 1982; Van Dijk, Kintsch, \& Van Dijk, 1983; Zwaan \& Radvansky, 1998). We operationalized this aspect in our discourse analysis by the variables of a) verb tense, and $b$ ) deixis.

2) Subjectivity aspect: identifies the person of the narrator, as well as his/her positioning with respect to the story world in which narrated events take place. We operationalized this aspect by the variables a) grammatical subject person, and b) number in the given intonation unit, and c) the narrator's being/not being a participant of the story world (Beran \& Unoka, 2005; Genette \& Sheridan, 1982).

3) Intentionality aspect: Defines the narrator's attitude towards his/her own person, and towards other characters as mental agents. We operationalized this aspect with three variables: a) focalization, b) agency and c) patiency.

4) Discourse level aspect: Positions the narrator in terms of his/her identifying with the narrator, or character of the story, or talking in the here and now of the therapeutic situation. Represents different types of remembering and self-knowledge: semantic, or general vs. episodic level. 


\section{Methods}

\section{Participants}

Participants were volunteers, and received no compensation for participating in the study. The therapist participating in the study is an experienced clinical psychologist and psychoanalyst in Budapest, Hungary. She is a member of the Hungarian Psychoanalytic Association and IPA. The treatment method applied was psychoanalysis. The therapist filled out the Clinical Data Form (CDF), which is a clinician-report form that assesses a range of variables about the client relevant to demographics, diagnosis, and etiology (Westen, Shedler, Durrett, Glass, \& Martens, 2003).

The client - whom we are going to call Clara in the analysis - is an undergraduate university student in her 20's, living in Budapest, Hungary. Based on the therapist's assessment in CDF she suffered from generalized anxiety disorder, sexual dysfunction and dependent personality disorder. Her love partnerships were unstable. She was able to develop stable friendships and was able to work and study at the same time, being rather effective in both. Her family history contributed to her emotional problems: she grew up in an instable family, and her parents were divorced when she was 13. Her mother suffered from anxiety disorder and eating disorder. Her father suffered from alcohol dependence.

\section{Procedure}

\section{Data collection and sampling}

The data for the current study has been collected as part of the Budapest Psychotherapy Database, a systematically collected and transcribed set of psychotherapy sessions in Hungarian language. The database consists of the audio-recording of therapeutic treatment in psychodynamic psychotherapies with two patient-therapist dyads for a period of 1.5 years into treatment from the onset of therapy. Between 2004 and 2006 five consecutive sessions at the beginning, middle, and last third of the observation period were audio-recorded. The current study consists of a qualitative analysis of the transcribed text of one therapy session with a female therapist - female client dyad. The session examined here is from the beginning phase of the observation period, a few months after beginning therapy.

\section{Selecting excerpts from the full transcript for data analysis}

Using theoretical sampling method we analyze 5 excerpts from the session containing almost all of the dialogue from the trauma-narrative construction process. The choice of these particular sequences from the complete transcript of the sessions was based on our aim to follow through one thread of themes of discussion taking place at the session, namely: the actual psychoanalytic process of revealing the sexual abuse experience of the patient. The process begins with the client's recollection of her dream, and ends at roughly in the middle of the session, with the patient finally revealing her traumatic relationship with an abusive partner. This is the point until we follow the events of the session in this paper, due to space limitations, and also, because after revealing the trauma narrative, another type of therapeutic activity proceeds - the discussing and working through this experience - which is outside of the scope of this paper. In our 
analysis of excerpts, we first present the patient's dream narrative in its complete form (Excerpt 1). Following this sequence, part of the transcript was not analyzed here due to space limitations; however, we were careful not to leave out any segment of the dialogue that would contain crucial information for readers to understand the narrative construction process. Excerpt 1 is followed by 4 additional consecutive dialogue sequences (Excerpt 2 - Excerpt 5), allowing for a continuous monitoring of the progressing narrative construction. We present all excerpts in English translation, which has been overseen by a native speaker. See Appendix C for the original Hungarian text.

\section{Recording of session}

Audio recording of sessions was carried out by participant analysts using a Sony min-disk device. Audio-recording as opposed to video-recording was chosen in order to avoid interference with the therapeutic work as much as possible. Asking participant analysts to do the recording themselves, served the same purpose of avoiding intrusion. The treatment method implied the classical arrangement of the client laying on the couch with the therapist sitting near her head. The consequence of this arrangement regarding the interaction was that the interactors' facial expressions were not visible for each-other, body and hand gestures were minimized, thus mainly reducing the relevant communicative aspects in the interaction to verbal content, tone of voice, and pauses.

\section{Ethical considerations}

The study for creating the Budapest Psychotherapy database, and its scientific analysis was approved by the board of Semmelweis University Regional and Institutional Committee of Science and Research Ethics. After the procedure(s) had been fully explained to them, participants signed the informed consent form in which they agreed to the use of their material for scientific and educational purposes. Also, participants were informed that they had the chance to resign at any point of the observation period if they felt uncomfortable. Recordings of sessions were carried out by the participant therapist; thus researchers did not meet clients personally. In order to preserve anonymity of the participant clients and therapists we deleted all personal information from the text-files, such as names of persons, places, institutions, dates of events, etc.

\section{Data transcription}

Audio-recorded therapy sessions were transcribed by the first author using the CHILDESS system (MacWhinney, 2000). The list of transcription codes used in this particular data-set is presented in the Appendix. The talkers' speech was transcribed verbatim, segmenting the speech flow into intonation units, as defined by Chafe (1994) in English, and by Németh (1996) in Hungarian. According to this, an intonation unit was defined as a group of words bounded by silence, a short pause or final intonation to signal question, period, or exclamation. Single words, sentence fragments could also be considered separate utterances, or fragmented utterances. The method of segmentation was tested for inter-rater reliability, and showed high level of agreement (Berán, Unoka, \& Czobor, 2011), agreement between two people who segmented 300 common intonation lines was $88,08 \%$ volt (chi-squared $=13,79, \mathrm{p}<.01$ ). Inter-class correlation inter-rater reliability (Shrout-Fleiss reliability point) $=.99, \mathrm{p}<.01$. Translation of the transcript into English was overseen by a native speaker of English. 


\section{Coding of NP}

Coding of NP was based on the original transcript in Hungarian, using the coding system we created for analyzing therapeutic discourse (for coding manual write to first author). We used the following variables in coding NP for individual intonation unit lines:

1. Verb tense: the grammatical verb tense in Hungarian includes three categories we used: a) past, b) present, and c) future.

2. Deixis: Adverbs of time and location, and demonstrative pronouns. We distinguished a) proximal, b) distal, and c) mixed categories, as well as d) "no deixis" present in a given intonation unit.

3. The narrator's relation to the story world (i.e., 'diegesis'): The narrator may be a) part of the story world ('inside-narrator'), or may be b) looking at it from the outside ('outside-narrator'). The narrator may c) identify with a character and tell the story from their point of view ('pseudo-narrator').

4. Grammatical subject: number and person. This is the same in Hungarian as in English. The subject could be a) singular or b) plural, and a) first, b) second, c) third person. We also distinguished two further categories of grammatical subject: d) impersonal (general) subject, or e) no subject present.

5. Mode of focalization: We differentiated a) internal mode of focalization: intonation units expressing mental contents (emotions, desires, intentions, etc.), from b) external mode of focalization: describing only overt behavior and events, but not the mental world of the participants.

6. Agency and patiency: Who is the actor in the story, who is influencing events in an active way, and who is the one who passively suffers the consequences: a) Self-agency/, patiency, b) Self-part agency/patiency, c) Other person-agency, patiency, d) Object-agency, patiency, e) No agent, or patient included in the given unit of analysis.

7. Discourse level: Positions the narrator in terms of whether he/she is telling the story from the narrator's point of view (i.e., narrator's level), or a character's point of view (i.e., character's level), or talking in the act of narration, in the here and now position of the therapeutic session ("here and now" of the therapeutic session"). These levels are also related to the process of recall, based on differing types of memory structures. The narrator is recalling general autobiographical information or a specific episode, or talking about the thoughts and feeling related to what is happening in the present (therapeutic session).

8. Coding for the segments included in the paper was independently carried out by the two authors, and disagreements were discussed and resolved afterwards. However, inter-rater reliability was computed based on 300 intonation units of the total transcript coded by independent ratings of the authors. Cohen's kappa for all the variables was between .55 and .76 (verb tense: .76; subject number: .69; subject person: .72; mode of focalization: .70; discourse level: .56; agency: 0. 67; patiency: .55).

\section{Micro-Analysis of Excerpts from the Psychotherapy Session}

\section{Dream narrative}

At about 10 minutes after the beginning of the session, the client, Clara, starts recollecting a dream. As she claims at a later point of the session the dream has popped into her mind just after leaving from the previous meeting. Her ambivalence about issues 
of agency and control emerge even in relation to recollecting her dream, as she reports to the therapist: "and I was very happy that, that I finally ... like I was able to realize, that that I really forget things". Following the recollection of her dream after the previous session however, she had what she described as a "horribly bad day", experiencing psychosomatic symptoms such as a strong headache.

In Excerpt 1 we quote the client's dream narrative that serves as a basis for later discussion at the session. See the Appendix for original transcript in Hungarian for all excerpts, and for transcription codes.

\section{Excerpt 1}

220 C: So this was my dream Monday morning, right.

$221 \mathrm{C}$ : and er ooo+...

comment: pause $26 \mathrm{sec}$

222 C: er I can't.

comment: pause $4 \mathrm{sec}$

223 C: well, so...

224 C: so, I had a dream about Laci,

$225 \mathrm{C}$ : and er+...

comment: pause $4 \mathrm{sec}$

$226 \mathrm{C}$ : so, like,

227 C: I don't know like+...

$228 \mathrm{C}$ : we met,

$229 \mathrm{C}:$ and then,

23o C: erer+...

$231 \mathrm{C}$ : we started like kissing,

$232 \mathrm{C}$ : then a sort of foreplay started, right,

$233 \mathrm{C}$ : which er er at the end was only+...

$234 \mathrm{C}$ : that erer...+

$235 \mathrm{C}:+$, so like er+...

$236 \mathrm{C}$ : we have already got each other undressed and all,

$237 \mathrm{C}$ : and so I was like $+\ldots$

238 C: kissing his belly,

$239 \mathrm{C}$ : and pulling down his his pants,

24o C: and there was nothing there. \#\#

$241 \mathrm{C}$ : and so like er+...

$242 \mathrm{C}$ : it was childish patterned underwear he wore.

243 C: like children's+/

$244 \mathrm{C}$ : that kind of a children's $+\ldots$

$245 \mathrm{C}$ : underwear.

It is apparent that in the dream sequence, that the therapist does not interrupt the client's narrative; thus, she does not influence the client's way of reconstructing her story. Examining the use of NP in the dream, we find that the client uses past tense throughout the narrative. Remembering in this perspective - despite using a first person subject creates an emotional distance between the dream-self and the present self of the narrator. Using exclusively past tense in self-narratives - in contrast to, for instance, alternating past tense with present tense - results in reduced emotional involvement as perceived by the listener (Berán et al., 2011; Pillemer, Desrochers, \& Ebanks, 1998; Polya, Laszlo, \& Forgas, 2005; Schiffrin, 1981). The effect of reduced affect is further supported by the 
fact that the emotional interpretation of self and other is missing in the story. The narrator, Clara, focuses on merely the behavior of the two main characters (Clara and Laci, her formal romantic partner); however, their thoughts, feelings, emotional reactions are not mentioned. Inner experiences are not described. From line 240 to 245 only the external appearance of the lover's missing sexual organ is reported, but the narrator's and/or her partner's emotional reaction is not. The narrator's strategy of focusing on events and visual effects (i.e., using external mode of focalization) instead of recounting thoughts and emotions has been reported often to be used in trauma narratives.

The expression of agency in the narrative is characterized by the frequent use of selfagency by the narrator. This means, that Clara portrays herself as active, willing participant of events, who is capable of influencing outcomes, and is responsible for them -- as opposed to being a passive sufferer of the consequences of another's actions. Examples for this are expressions like "I had a dream", "I don't know", "we started kissing", "we started to undress each-other".

However, a non-living object takes the place of the agent, at various points in the narrative, such as in lines 240-245, where the agent becomes "nothing", and "children's underwear". This latter use of non-living object agency is related to the negation of the penis on the part of the dreamer. From a psychoanalytic point of view, the narrator/dreamer here makes the penis disappear, denies its existence, or destroys it, which is an aggressive way of relating the self to the object. This object in fact is part of the lover's body, or in general, part of the male body. Thus, the relationship between the self and the other person is an aggressive one here - the actor, or aggressive agent being the narrator/dreamer. One might speculate, that the fact that agency is being delegated to the object ("nothing", or "children's underwear") suggests that the narrator is ambivalent about relating aggressively to the other. Nevertheless, the client/narrator appears in the dream narrative as an active, capable, assertive, or even aggressive agent.

\section{Sexuality, disgust and aggression}

Clara's complex relation to male sexuality or other is further elaborated in the discussion following the dream narrative. In her free associations she begins to describe emotional and physical difficulties related to her sexual life (i.e., oral sex). In Excerpt 2 the discussion continues on this topic.

\section{Excerpt 2}

$276 \mathrm{C}$ : but that..+

$277 \mathrm{C}$ : that this is...+

$278 \mathrm{C}:+$, that this is something horrible for me+...

$279 \mathrm{C}:+$, disgusting,

$280 \mathrm{C}$ : appalling!

$281 \mathrm{C}$ : like it makes me wanna vomit,

$282 \mathrm{C}$ : but really concretely,

$283 \mathrm{C}$ : and like er er+...

284 C: I am scarred,

$285 \mathrm{C}$ : and at the same time,

286 C: I mean very severe,

$287 \mathrm{C}$ : I think it is a severe impairment that,

$288 \mathrm{C}$ : that I am not able to do this. 
The first important shift in this sequence is the use of discourse level 3, what we called the here-and-now of the therapeutic session. In contrast to the character or narrator levels, level 3 is characterized by the narrator's stepping outside of the story world, and talking about his/her actual thoughts and emotions directly to the therapist. In contrast to the dream narrative, in this "space" outside of the story world Clara is able to re-experience and express her negative, aggressive, and avoidant emotions related to the penis.

The specific NP shifts that occur in this section provide further support for this claim. In contrast to the NP of external focalization used in the dream-narration, Clara uses internal focalization, with intense emotion expression while talking about oral sex, expressing her disgust and fear related to it. She also uses present tense throughout this section in first person singular, which perspective expresses an increased involvement of the self (Schiffrin, 1981), as compared to the past tense used in the dream narration.

Looking at agency in Excerpt 2 we find a dominance of non-living object agency in the client's use of perspectives, the agent being oral-sex, or "impairment". At the same time, self-patiency is used in line 281-284. This use of agency in the discussion of strong emotions and feelings suggests that Clara portrays herself as a helpless and a passive sufferer, who must suffer the effects that certain objects produce in her (i.e., penis), or the consequences in her circumstances. In line 286-88 self-agency returns in the use of "I mean", "I think", "I am not able to". This again suggests that Clara is the responsible actor for outcomes and events, however, in this case, agency also represents self-blame.

\section{The therapist's intervention}

The following excerpt is a continuation of excerpt 2. Its most important event is the therapist's intervention and the client's reaction to it.

\section{Excerpt 3}

289 T: yes, well the boys-

290 T: did they say that,

$291 \mathrm{~T}$ : this is an impairment?

292 C: no!

293 C: no.

294 C: but like+...

$295 \mathrm{C}$ : expecting it,

296 C: like that...+

$297 \mathrm{C}$ : there were a few of them,

298 C: who would have expected it,

299 C: but I am not capable of it.

$300 \mathrm{C}$ : I can't do it.

$301 \mathrm{~T}$ : and what was their response.

$302 \mathrm{~T}$ : when you were not able to do it?

303 C: well + ...

$304 \mathrm{C}$ : nothing.

$305 \mathrm{C}$ : well, obviously nothing.

$306 \mathrm{C}$ : that it's ok, of course.

The therapist's intervention is a radical shift in comparison to the patient's perspective in 289-291 in several aspects of NP. First, she introduces "the boys" as actors, positioning 
them as agents. This use of agency calls into question the client's previous interpretation of events, her taking responsibility for outcomes, and her self-blame. In contrast to Clara's internal focalization, the therapist uses external focalization: talking of the boys' behavior, not about their thoughts, or emotions. The therapist also uses outside-narrator, looking on the events from outside of the story-plane, hence differentiating ,the boy's" as well as the client's previous perspective from her own. She also shifts into narrator's position, where causal connections may be examined with more emotional distance, at a higher level of knowledge. The therapist's shifts of perspective represent a lower level of emotional involvement in comparison to Clara's former perspective used in 284-288. Thus, the therapist's shifting of NP in 289-290 down-regulates the intensity of emotional involvement. Table 1 summarizes the differences in perspective between the talkers.

Answering the therapist's question with "no" for short - meaning: "No, the boys did not say that this was impairment" - Clara also takes on the perspective offered in 284-288 by the therapist. However, she shifts back again to her previous point of view by using internal focalization in 294 C for "the boys", guessing their mental content (expectations). Then, again she uses self-agency in 299-300, taking responsibility and blame for what she sees as her incapacity. Thus, the talkers take conflicting point of views regarding the agent's identity, as expressed in their perspectives: the therapist using "the boys" and the client herself (Clara) as agent. This suggests that despite self-agency implying, in this case, self-blame, giving it up is not an easy step for the client.

Reacting to the client's statement, the therapist's next move - in line 301 - is shifting perspective again, by using "response" as an object-agent. Clara accepts this perspective and also uses object-agency in her answer in 303-306. Thus, the "agent" that is acceptable for both, is being negotiated by the talkers: first the therapist shifting into object-agency, then the client. Hence, at this point they come to an agreement on the question.

\section{Who is the agent?}

Excerpt 4 is a continuation of the discussion which centers on the question of emotional terror - an important part of the client's experience of sexuality. Problems with agency dominate the discussion in this section as well.

\section{Excerpt 4}

307 C: yes,

$308 \mathrm{C}$ : but that...+

$309 \mathrm{C}$ : but that led to emotional terror always.

$310 \mathrm{~T}$ : on your part.

$311 \mathrm{~T}$ : according to this.

312 C: yes.

$313 \mathrm{~T}$ : so it weren't the boys $+\ldots$

314 C: no!

$315 \mathrm{~T}:+$, er er who complained about this-

$316 \mathrm{C}:$ no!

$317 \mathrm{C}$ : it was me, myself.

$318 \mathrm{~T}$ : you felt that way+l

319 T: you yourself felt that way,

320 T: that you should be able to do this. 
$321 \mathrm{~T}$ : or that this is not right.

$322 \mathrm{C}$ : well, yes.

The section is characterized by the talkers clarifying Clara's feelings of emotional terror using the narrator's level. As we mentioned earlier, the shift of NP to the narrator's level was initiated by the therapist in 289-290, and repeated again in her question in 301-302. As a response, the client also shifted to the narrator's level in 303, holding on to this perspective throughout Excerpt 4. Since this position signals a reduced level of selfinvolvement, shifting to the emotionally less intense position allows the client to differentiate her formal self — as a character of the story — and her present position.

This differentiation of the client's former and current positions allows her to focus on her feelings of terror - using internal focalization mode - without being overwhelmed by it. In 307-309 Clara uses general subject (impersonal), and object agency to describe events related to the "terror". Her perspective prevents the listener from identifying who used emotional terror against whom. In reaction to this obscuring of the agent's identity, the therapist uses various NP shifts to test hypotheses about the client's view of the agent's identity. In 310 the therapist directly asks the client who was responsible for her feelings of terror. The therapist uses second person, putting Clara in the passive position of the patient, in internal focalization. The therapist's NP in 313, 315 regarding subjectivity and intentionality aspects is in contrast with her perspective in 318-321, as it is shown in Table 2. Thus, the therapist offers two contrasting perspectives, one of which is verified by the client in turn, in 322 .

Despite the client's explicit agreement with the therapist's perspective of agency in 318321 , there are two contrasting views, or alternative possibilities of agency presented in the therapist's question, "mirroring" the client's previous perspective. This strategy on the therapist's part - whether conscious or not - opens up a new possibility for the client to discuss the issue further, perhaps elaborate on it more. Thus, the therapist's offering of alternative views of agency is followed by Clara's shifting of NP, and her recollection of her trauma of a sexual abuse experience in Excerpt 5.

\section{Trauma narrative}

\section{Excerpt 5}

$323 \mathrm{C}$ : 'cas actually in my first-

$324 \mathrm{C}: \mathrm{m}$ like sexual relationship,

$325 \mathrm{C}$ : this has been like a very serious problem.

$326 \mathrm{~T}: \mathrm{hm}$.

$327 \mathrm{C}$ : so that like $+\ldots$

$328 \mathrm{C}$ : that that boy could make the worst humiliations $\mathrm{m}$ out of that.

327 T: you haven't told me about this yet.

328 C: no.

comment: pause $7 \mathrm{sec}$

$329 \mathrm{C}: \mathrm{mm}$ erer+...

$330 \mathrm{C}$ : he was a German guy,

$331 \mathrm{C}$ : and that $+\ldots$

$332 \mathrm{C}$ : well he $\mathrm{m}+\ldots$

$333 \mathrm{C}:+$, this was his request in fact.

$334 \mathrm{C}$ : and I told him that I couldn't do it, 
$335 \mathrm{C}$ : and I am not able to do this,

$336 \mathrm{C}$ : he just simply like+...

$337 \mathrm{C}:+$, pushed down my head.

$338 \mathrm{C}:$ and $\mathrm{so}^{+} \ldots$

$339 \mathrm{C}$ : he demanded it.

$340 \mathrm{C}$ : or made me kneel like on the floor.

Claras's recollection of her sexual experience with an abusive person involves a radical shift of perspective, in comparison with her previous point of view either in her dream narrative, or in the discussion following it. Looking at these shifts of perspective we find the following:

From line 322 to 328 the client continues using the narrator's position. This emotionally less involving position allows for a wider scope on narrated events, and generalizations across experiences in various episodes, as well as the integration of contradictory perspectives. There are two contradictory narratives to be integrated here: one involves Clara's taking the agent's position, and taking responsibility for events, using self-blame. The other involves Clara's powerlessness, suffering and humiliation, and potentially the experience of anger. The former position is represented by the dream narrative, whereas the latter is represented by the trauma narrative. The dream narrative is a fantasy, expressing the desire of overcoming powerlessness that is represented by the trauma narrative. This latter may be assumed to reflect the outside real events, and the narrator's experiences of that reality.

In terms of NP used in the trauma narrative, we find a shift of agency in line 330. The new agent becomes a concrete person, referred to as "that boy" or "a German guy" - as opposed to former general reference to other agents, such as "boys". As "a German guy" becomes the agent, Clara becomes the patient at the end of the trauma narrative, being subjected to abuse and aggression. In 336-340 first a body part, or part of the self (head) is being put into the patient's position, then the whole self appears as the passive sufferer.

Along with abandoning the position of the agent, in 334 Clara shifts her point of view from narrator to character position, recounting the episode of abuse in detail. This perspective expresses a more intense emotional involvement of the self. However, emotions or mental contents of the participant self and other are not narrated: external focalization is used - similarly to the dream narrative. NPs used in the dream narrative and in the trauma narrative are summarized in Table 3.

\section{Discussion}

In the above five excerpts we have analyzed the first 25 minutes of a psychodynamic therapy session. Starting out with a dream a story, as the interaction between patient and therapist progressed, the narrative of a repeated sexual abuse has been revealed. With respect to the talkers' use of NP, more specifically, perspectives of agency and patiency, the dream and trauma narrative may be contrasted in several aspects (as shown in Table 3) showing a shift in the client's perspective:

In the dream narrative as well as in the client's initial associations to the dream the self appears as the agent, whereas the patient of the narrative is the other person, a male lover, or an inanimate object, which is part of the "other" male body (penis). In the course of the 
interaction this narrator-agent at times appears to be a) initiating actions, for instance, when undressing the lover, b) aggressive, for instance, by making the penis disappear, or c) responsible for outcomes, such as unsuccessful love relationships. In the trauma narrative the narrator's self and part-of-self is put in the position of the patient. The agent is the other (male), who is being aggressive, and b) controlling and abusing the narrator, and c) is responsible for outcomes such as abusive behavior and unsuccessful love relationship.

Thus, in the two narratives the position of agent and patient is switched between the self and other. In the dream, the self is in the position of the agent - the other is in the position of the patient, whereas in the client's reconstructed memory of the abuse narrative it is vice versa. The first, dream situation may be considered as the client's fantasy wish, whereas the second one is a reconstruction of a real life experience, probably a close enough description of what actually took place from the client's point of view at the time of events.

In our analysis we have shown that the therapist's role in the joint construction of the abuse narrative has been a facilitating one. She initiated shifts by shifting to a new perspective in her interventions, offering new potential point of views to the client. This way she helped the client to shift her own perspective: from agency to patiency, shifting back and forth between character to narrator levels, from external to internal focalization mode, etc. Thus, the therapist's shifting behavior gave new direction to the unfolding of the narrative at various points of co-construction with her initiating a sequence of shifts directed towards a specific aim to change the client's point of view regarding positions of agency and patiency. Such important shift was for instance, when the therapist mentioned "the boys" as potential agents in the story providing an opportunity for the client to consider other actor's active role in outcomes and responsibility besides herself.

We argue that the psychological significance of the client's going through a gradual shifting of perspective is that she is able to re-construct the traumatic event, and renarrate it from a different point of view. In her trauma narrative Clara abandoned the position of the agent she took initially in the dream narrative as well as in other fragments of her self-narrative discussing her love-life. Her initial position had the psychological advantage of protecting the client from experiencing negative emotions of powerlessness; however, it also involved the client's experiencing other negative emotions such as guilt, and self-blame in a maladaptive way. These on the long run lead to relationship difficulties and contributed to her low self-esteem in relationships.

Shifting into a new perspective in terms of agency — patiency and re-constructing her trauma narrative has two important consequences for the therapeutic process: First, it allows the client to gradually re-experience difficult emotions from the past, while reorganizing her memory of the traumatic events (Allen, 2001; Conway, 2001). As it is shown in Table 3 at this point of the therapy session, the trauma narrative has not yet included internal focalizing perspectives: references to mental states of self and other, which could verbally reveal the re-experiencing of such emotions (Unoka, Berán, \& Pléh, 2012). However, some negative emotions of disgust and fear the client mentioned at an earlier point in the session could be reorganized in a more realistic narrative of her emotionally confusing abuse experiences in the future. In her reconstructed narrative she will be able to include experience of fear, shame, disgust, and humiliation, as well as experience of powerlessness and passivity. Moreover, from this point on in therapy, the 
possibility of dealing with negative emotions and also of working through them opens up. Second, while recalling her abuse experience that has occurred in her first intimate relationship, as she puts it, the client shifts into a NP that expresses and acknowledges her passive role in the abuse situation. This is in contrast to the client's initial positioning of herself as agent in her sexual interactions excluding the possibility of others' responsibility. As a result of her position as agent, the client was suffering excessive selfblame and feelings of guilt taking responsibility for her own negative experiences in the abuse situation itself, as well as for long term outcomes in the form of relationship problems she mentions earlier in the session. The reconstructed abuse narrative positions Clara as the patient, hence allowing the lessening of guilt and self-blame.

Recovering the abuse narrative and accepting experiences of passivity and powerlessness on the part of the client creates a linguistic representation of experiences which integrates episodic memories of the traumatic event with the autobiographic knowledge-system (Allen, 2001; Beaudoin, 2005; Conway, 2001; Kaminer, 2006) including new, reconstructed self and other representations. Thus, as a result of transformed narrative the client's self-representations may include her genuine feelings of powerlessness, pain and sadness, as well as the therapist's emphatic reactions to these experiences, which reduce, for instance, feelings of shame associated with them. The newly experienced self and other representations help the healing processes by fostering reconstruction and reconsolidation (Gorman \& Roose, 2011) of the trauma episode in memory. This seems to be a necessary step towards recovering the client's sense of agency that allows a healthier way of relationship-functioning.

The process of joint reconstruction of the client's abuse narrative demonstrates how therapeutic process in psychodynamic psychotherapy can be studied using a micro-level discourse analysis. In a step by step description of shifts in NP in the client's talk, we followed the gradual transformation of her self-narrative. The therapist's active role in the process of reconstructing the client's narrative was also revealed by the analysis. By examining perspective shifts in the therapist's talk, we could trace effects of single interventions on the client's perspective shifts. We showed how in the course of the interaction, the therapist was able to influence the unfolding of the client's narrative, and hence, the construction of the narrative self by acting upon a crucial aspect of its structure-formation, namely the point of view from which the client tells her story.

\section{Limitations of Data-Interpretation}

We would like to mention two methodological concerns regarding our data interpretation, one is related to using verbal interaction as data source, the other to psychoanalytic theory used by the participant therapist. It has been pointed out in previous studies (Levitt \& Rennie, 2004; Levitt \& Piazza-Bonin, 2011) that there are important aspects of in-session interaction which are not verbally expressed, cannot even be overtly verbalized, hence cannot be assessed using textual analysis. Therefore, important aspects of the interaction may be overlooked in the type of analysis we undertook in this research. This is a limitation all discourse analysis of in-session interaction must deal with to some degree.

Modes of nonverbal communication typically studied as important sources of information not included in the above analysis are facial emotional expressions, hand and body gestures and tone of voice. As we mentioned in our Method section however, the arrangement of the psychoanalytic setting radically reduces the relevance of facial 
expressions, hand and body gestures in the communicative process. Due to the limitation of the scope of our analysis we did not include analysis of tone of voice, ad pauses, although these could be revealing of emotion states of the talkers. Since we included this information in our transcript, this aspect of therapeutic discourse may be the topic of future studies.

Since our framework for data analysis is a discourse based narrative analysis, the question may arise how this framework is related to psychoanalytic theory used by therapist in her interpretation of in-session events and the client's narrative. First, we must note that using the narrative/discursive framework does not exclude, nor contradict any psychoanalytically grounded interpretations or explanations of the therapeutic process, in fact, this method could be used to further investigate psychoanalytically based explanations, or elaborate on certain aspects of them. In addition we think that while our analysis is based on data from psychodynamic psychotherapy, this method may also be used for examining therapeutic process in therapies using different theoretical backgrounds and techniques such as client centered, expressive, etc. as long as there is narrative construction taking place at the session. Secondly, although there is example in the literature how additional information from the therapist may be used for interpreting in-session discourse events, for instance, in the classic study by Labov and Fanshel (1997), there are a great number of studies of therapeutic discourse not using this secondary source of information while providing valid analysis of in-session interaction grounded in discourse theory such as conversation analysis (Voutilainen, Perakyla, \& Ruusuvuori, 2011).

There is another, theoretical limitation we must consider regarding our analysis. We must emphasize that reconstruction of the trauma narrative is just one element of the therapeutic process, perhaps not always the first step. The problem of recovering agency in traumatized patients might be complicated and influenced by various factors different for each individual case. Such influential factor may be, for example, the severity of the trauma. If the client repeatedly experiences flashbacks and other sudden intrusions of the traumatic memories, regaining the capacity of self-agency in the traumatized part of his/her personality is a long and complex process (Berán \& Unoka, 2005). Thus, various interventions, such as helping to develop emotion regulation skills of the client may be necessary before reconstructing agency in the trauma narrative.

\section{Implications for Psychotherapy Process Research and Clinical Treatment}

Based on our analysis of in-session interaction there are two considerations to keep in mind regarding future research of psychotherapy process:

1) Analyzing the psychotherapy process by studying narrative co-construction taking place between client and therapist with a focus on the interactive process of perspective shifting of the talkers.

2) Presenting a new way of conceptualizing and analyzing the effect of single interventions by studying interactive shifting behavior.

Regarding clinical practice our theory of NP regulation in this and other studies was shown to be useful for describing relevant discourse events in the therapeutic interaction in terms of transformation of the client's narrative. The fact that we showed how, and in 
what way the psychoanalyst is able to influence the reconstruction of the narrative may have interesting consequences for clinical practice. According to our results, the construction of the narrative self is influenced by the therapist by acting upon a crucial aspect of its structure-formation, namely on the NP or point of view, from which the patient tells his/her story. Further examination of the details of this process in case studies dealing with various psychological problems could provide useful information for therapeutic training and practice. Future studies are needed to find out whether shifting perspective is a "technique" that could be applied at will and practiced by therapists online, or conscious control of most aspects of language use concerning perspective is not probable in spontaneous speech production at the session; also, whether learning particular type of shifting behavior may generalize to other similar situations as a cognitive skill.

We found that shifting into a given perspective or elaboration of certain perspectives might be uncomfortable for the client at a given moment in therapy, or it may even prove impossible. Hence, learning particular NP shifts is not accomplished as a one-time event. Rather, shifting from one particular perspective to another - as initiated by the therapist - is often accomplished in multiple steps (i.e., sequences of shifts) by the client. Thus, it is a prolonged process that takes place over an extended period of time spent in psychoanalysis, practicing certain shifts by "repetition".

\section{Authors' Note}

This research was supported by OTKA PD 108868, 2013-2016 the Hungarian National Research Foundation, and the Research Board of the International Psychoanalytic Society.

\section{Biographical Note}

Eszter Berán, Ph.D., is assistant professor at Pázmány Péter Catholic University, Budapest, Hungary. She teaches at the Department of Developmental and Clinical Child Psychology. Her research concentrates on psychotherapy process, and on mechanisms of change in psychodynamic psychotherapy. She approaches these problems from a narrative angle using discourse analytic methods. She is also interested in gender issues, and conducts research related to life history, gender and psychopathology.

Zsolt Unoka, M.D., Ph.D., is associate professor of psychiatry at Semmelweis University, Budapest, Hungary, at the Department of Psychiatry and Psychotherapy and head of the Sub-department of Psychotherapy. He is a member of the teaching faculty of the Graduate and Postgraduate Psychotherapy Training Program at Semmelweis University. $\mathrm{He}$ is a psychiatrist, psychotherapist, and psychoanalyst and a member of the Hungarian Psychoanalytical Society. His research interest is psychoanalytic process research (narrative interaction), and social-cognitive-affective disturbances in Borderline Personality Disorder. 


\section{References}

Adler, J. M., Skalina, L. M., \& McAdams, D. P. (2008). The narrative reconstruction of psychotherapy and psychological health. Psychotherapy Research, 18, 719-734.

Allen, J. G. (2001). Traumatic relationships and serious mental disorders. John Wiley \& Sons Ltd.

American Psychiatric Association \& American Psychiatric Association.Task Force on DSM-IV. (1994). Diagnostic and statistical manual of mental disorders: DSM-IV. Amer Psychiatric Pub Inc.

Beaudoin, M. N. (2005). Agency and choice in the face of trauma: A narrative therapy map. Journal of Systemic Therapies, 24, 32-50.

Beran, E. \& Unoka, Z. (2005). Construction of self-narrative in psychotherapeutic setting: an analysis of the mutual determination of narrative perspective taken by patient and therapist . In U.M.Quasthoff \& T. Becker (Eds.), Narrative interaction (5 ed., pp. 151-169). John Benjamins Publishing.

Berán, E., Unoka, Z., \& Czobor, P. (2011). A szelf affektív bevonódása a pszichoterápiás folyamatba: érzelmi intenzitás kifejezése narratív perspektívahasználattal a terápia kezdeti szakaszában. Pszichológia, 31, 237-257.

Bremond, C. (1973). Logique du récit. Editions du Seuil.

Bromberg, P. M. (2003). Something wicked this way comes: Trauma, dissociation, and conflict: The space where psychoanalysis, cognitive science, and neuroscience overlap. Psychoanalytic psychology, 20, 558.

Chafe, W. (1994). Discourse, consciousness, and time: The flow and displacement of conscious experience in speaking and writing. University of Chicago Press.

Clark, H. H. (1996). Using language. (4 ed.) Cambridge University Press Cambridge.

Conway, M. A. (2001). Sensory-perceptual episodic memory and its context: Autobiographical memory. Philosophical Transactions of the Royal Society of London.Series B: Biological Sciences, 356, 1375-1384.

Conway, M. A., Harries, K., Noyes, J., Racsma'ny, M., \& Frankish, C. R. (2000). The disruption and dissolution of directed forgetting: Inhibitory control of memory. Journal of memory and language, 43, 409-430.

Conway, M. A., Singer, J. A., \& Tagini, A. (2004). The self and autobiographical memory: Correspondence and coherence. Social cognition, 22, 491-529.

Genette, G. \& Sheridan, A. (1982). Figures of literary discourse. Columbia University Press New York.

Gorman, J. M. \& Roose, S. P. (2011). The neurobiology of fear memory reconsolidation and psychoanalytic theory. Journal of the American Psychoanalytic Association, 59, 1201-1220.

Habermas, T. (2006). Who speaks? Who looks? Who feels? Point of view in autobiographical narratives1. The International Journal of Psychoanalysis, 87, 497518.

Habermas, T. (2012). Identity, emotion, and the social matrix of autobiographical memory: A psychoanalytic narrative view. Understanding autobiographical memory: Theories and approaches, 33-53.

Herman, J. L. \& Schatzow, E. (1987). Recovery and verification of memories of childhood sexual trauma. Psychoanalytic psychology, 4, 1.

Jackendoff, R. (1992). Language of the mind: Essays on mental representation. Language of the Mind: Essays on Mental Representation.

Kaminer, D. (2006). Healing processes in trauma narratives: A review. South African journal of psychology, 36, 481-499. 
Karlsson, M. M. (2002). Agency and Patiency: Back to Nature? Philosophical Explorations, 5, 59-81.

Keskinen, S. (2004). Between Abstract Individualism and Gendered Lives: Negotiating Abused Women's Agency and Identity in Therapy.

Labov, W. \& Fanshel, D. (1997). Therapeutic Discourse Psychotherapy as Conversation. New York, NY: Academic Press.

Ref Type: Generic

Lane, R. D., Ryan, L., Nadel, L., \& Greenberg, L. (2014). Memory Reconsolidation, Emotional Arousal and the Process of Change in Psychotherapy: New Insights from Brain Science. Behavioral and Brain Sciences, 1-80.

Levitt, H. M. \& Piazza-Bonin, E. (2011). Therapists' and clients' significant experiences underlying psychotherapy discourse. Psychotherapy Research, 21, 70-85.

Levitt, H. M. \& Rennie, D. L. (2004). Narrative activity. The handbook of narrative and psychotherapy, 299-313.

MacWhinney, B. (2000). The CHILDES Project: Tools for analyzing talk. transcription format and programs. (1 ed.) Routledge.

McAdams, D. P. (2001). Coding autobiographical episodes for themes of agency and communion. Unpublished manuscript, Northwestern University, Evanston, IL.

Nelson, K. \& Fivush, R. (2004). The emergence of autobiographical memory: a social cultural developmental theory. Psychological review, 111, 486.

Németh Enikő (1996). A szóbeli diskurzusok megnyilatkozás példányokra tagolása. Budapest: Akadémia Kiadó.

O'Kearney, R. \& Perrott, K. (2006). Trauma narratives in posttraumatic stress disorder: A review*. Journal of Traumatic Stress, 19, 81-93.

Ochberg, R. L. (1994). Life stories and storied lives. Exploring identity and gender: The narrative study of lives, 2, 113-144.

Pillemer, D. B., Desrochers, A. B., \& Ebanks, C. M. (1998). Remembering the past in the present: Verb tense shifts in autobiographical memory narratives. In Autobiographical memory: Theoretical and applied perspectives, 145-162.

Polya, T., Laszlo, J., \& Forgas, J. P. (2005). Making sense of life stories: The role of narrative perspective in perceiving hidden information about social identity. European Journal of Social Psychology, 35, 785-796.

Prince, G. (2003). A dictionary of narratology. U of Nebraska Press.

Schafer, R. (1976). A new language for psychoanalysis. Yale University Press.

Schiffrin, D. (1981). Tense variation in narrative. Language, 45-62.

Unoka, Z., Berán, E., \& Pléh, C. (2012). Narrative constructions and the life history issue in brain-emotions relations. Behavioral and Brain Sciences, 35, 168-169.

Uspenskij, B. A. Ź. (1973). A poetics of composition: The structure of the artistic text and typology of a compositional form. University of California $\mathrm{Pr}$.

Van Dijk, T. A., Kintsch, W., \& Van Dijk, T. A. (1983). Strategies of discourse comprehension. Academic Press New York.

Voutilainen, L., Perakyla, A., \& Ruusuvuori, J. (2011). Therapeutic change in interaction: Conversation analysis of a transforming sequence. Psychotherapy Research, 21, 348-365.

Westen, D., Shedler, J., Durrett, C., Glass, S., \& Martens, A. (2003). Personality diagnoses in adolescence: DSM-IV axis II diagnoses and an empirically derived alternative. American Journal of Psychiatry, 160, 952-966.

Zwaan, R. A. \& Radvansky, G. A. (1998). Situation models in language comprehension and memory. Psychological Bulletin 123, 162-185. 


\section{Appendix A}

\section{Transcription Codes}

The interaction was transcribed using the CHILDES (MacWhinney, 2000) coding system. Each line represents a full or broken intonation unit, realizing a given narrative perspective. At the beginning of each line there is a number signaling the place of the line within the transcript of the therapeutic session. The $T$ or $P$ following the number signals the speaker being the therapist or patient, respectively.

Final intonation contour at the end of full units:

\section{. falling}

? rising -- question

! exclamation

, level, continuing

Broken intonation units:

$+\ldots$ broken unit, fragment

$+/ / \quad$ interrupted by another speaker

+ self-interruption

,$+ \quad$ beginning of an intonation unit continuing a broken unit

Final intonation contour at the end of fragmented units:

-. falling

,$- \quad$ level

$-? \quad$ rising

/ emphasized word or syllable

\# (1 s) pause btw words or within words 


\section{Appendix B}

\section{Table 1}

Differences of perspective between talkers

\begin{tabular}{|l|l|l|}
\hline NP variable & NP in Client 284-288 & NP in Therapist 289-290 \\
\hline Agency & self-agency: Client & other-agency: the boys \\
\hline Focalization & internal focalization & external focalization \\
\hline Story world & inside-narrator & outside-narrator \\
\hline Subject person & $1^{\text {st }}$ person & $3^{\text {rd }}$ person \\
\hline Verb tense & present tense & past tense \\
\hline Discourse-level & here-and -now of the sessio & narrator's level \\
\hline
\end{tabular}

Table 2

The therapist offers two contrasting perspectives

\begin{tabular}{|l|l|l|}
\hline NP variable & $\underline{\text { NP in Therapist 313,315 }}$ & $\underline{\text { NP in Therapist 318-321 }}$ \\
\hline Agency & other-agency: the boys & other-agency: the client \\
\hline Focalization & external focalization & internal focalization \\
\hline Story world & outside-narrator & outside-narrator \\
\hline Subject person & $3^{\text {rd }}$ person & $2^{\text {nd }}$ person \\
\hline Discourse-level & narrator's level & narrator's level \\
\hline
\end{tabular}

\section{Table 3}

The client's perspective in dream narrative vs. trauma narrative

\begin{tabular}{|l|l|l|}
\hline NP variable & NP in Dream narrative & NP in Trauma narrative \\
\hline Agency & self & other person \\
\hline Patiency & $\begin{array}{l}\text { other person, non-human } \\
\text { object }\end{array}$ & self \\
\hline Focalization & external focalization & external focalization \\
\hline Subject person & first person & first person \\
\hline Story world & inside-narrator & inside-narrator \\
\hline Discourse-level & character level & narrator / character level \\
\hline
\end{tabular}




\section{Appendix C}

\section{Original transcript of excerpts from the therapeutic session in Hungarian}

\section{Excerpt 1}

220 C: ezt álmodtam ugye hétföre reggel.

$221 \mathrm{C}$ : és öö ooo+...

comment: pause $26 \mathrm{~s}$

222 C: öö nem megy.

comment: pause $4 \mathrm{~s}$

223 C: jó végül is így,

$224 \mathrm{C}$ : tehát hogy a Lacival álmodtam,

225 C: és ö $+\ldots$

comment: pause $4 \mathrm{~s}$

$226 \mathrm{C}$ : tehát így,

$227 \mathrm{C}:$ nm tudom így+...

228 C: találkoztunk,

229 C: aztán így,

$230 \mathrm{C}:$ öö + ...

$231 \mathrm{C}$ : úgy elkezdtünk csókolózni,

232 C: aztán ugye így elkezdődött egy ilyen előjáték,

$233 \mathrm{C}$ : ami öö ben végül is annyi volt $+\ldots$

234 C: hogy öö + ...

$235 \mathrm{C}:+$, hogy így ö + ...

$236 \mathrm{C}$ : már levetkőztettük egymást meg minden,

237 C: és hogy én így+...

238 C: puszilgattam a hasát,

239 C: és lehúztam a a nadrágját,

$240 \mathrm{C}$ : és nem volt ott semmi. \#\#

$241 \mathrm{C}$ : és ugye így ö+...

242 C: egy gyerekmintás alsónadrág volt rajta.

243 C: ilyen kisgyerek+/

$244 \mathrm{C}$ : amilyen a kisgyerekeknek a $+\ldots$

245 C: alsónadrágja.

... Interaction segment not included in the analysis

\section{Excerpt 2}

$276 \mathrm{C}$ : de hogy $+\ldots$

$277 \mathrm{C}$ : hogy ez+...

$278 \mathrm{C}:+$, hogy ez nekem valami iszonyú + ...

$279 \mathrm{C}:+$, gusztustalan,

280 C: undorító!

$281 \mathrm{C}$ : így konkrétan hánynom kell tőle,

282 C: de hogy egészen konkrétan,

283 C: és így öö+...

284 C: rettegek töle,

285 C: és közbe meg így,

$286 \mathrm{C}$ : szal ilyen nagyon,

287 C: nagyon súlyos fogyatékosságomnak élem azt meg, 
288 C: hogy én erre nem vagyok képes.

\section{Excerpt 3}

289 T: igen hát a fiúk,

290 T: azt mondták,

291 T: hogy ez egy fogyatékosság?

292 C: nem!

293 C: nem.

294 C: dehát így+...

295 C: elvárni,

296 C: azt így+...

297 C: voltak így többen,

298 C: akik elvárták volna,

$299 \mathrm{C}$ : de hát én meg nem vagyok rá képes.

300 C: nem tudom megtenni

$301 \mathrm{~T}$ : és mi volt a válasz.

302 T: amikor nem volt képes rá?

303 C: hát+...

304 C: semmi.

$305 \mathrm{C}$ : hát nyilván semmi.

306 C: hogy így jó, persze.

\section{Excerpt 4}

$307 \mathrm{C}$ : igen,

$308 \mathrm{C}$ : de hogy + ...

309 C: de hogy ebből ilyen lelki terror lett mindig.

310 T: a saját maga számára.

$311 \mathrm{~T}$ : ezek szerint.

$312 \mathrm{C}$ : igen.

$313 \mathrm{~T}$ : tehát nem a fiúk $+\ldots$

$314 \mathrm{C}:$ nem!

315 T: +, öö hányták a szemére,

$316 \mathrm{C}:$ nem!

317 C: én magam.

318 T: hanem maga érezte úgy+/

319 T: saját maga érezte úgy,

$320 \mathrm{~T}$ : hogy ennek mennie kellene.

$321 \mathrm{~T}$ : vagy ez így nincsen jól.

$322 \mathrm{C}$ : hát igen.

\section{Excerpt 5}

$323 \mathrm{C}$ : mer végül is nekem az első,

324 C: $m$ ilyen szexuális kapcsolatomban,

$325 \mathrm{C}$ : ez egy ilyen nagyon komoly probléma volt.

$326 \mathrm{~T}:$ ühm.

$327 \mathrm{C}$ : tehát hogy ilyen $+\ldots$

$328 \mathrm{C}$ : hogy a legdurvább megaláztatásokat bírta m belőle csinálni az a fiú.

327 T: erről még nem mesélt.

$328 \mathrm{C}$ : nem.

comment: pause $7 \mathrm{sec}$ 
$329 \mathrm{C}: \mathrm{mm}$ öö+...

330 C: ő egy német srác volt,

331 C: és hogy $+\ldots$

$332 \mathrm{C}$ : hát neki így $\mathrm{m}+\ldots$

$333 \mathrm{C}$ : +, ez volt a kérése, tulajdon képen.

$334 \mathrm{C}$ : és én mondtam hogy én ezt nem tudom megtenni,

$335 \mathrm{C}$ : meg én erre nem vagyok képes,

336 C: ő meg egyszerüen csak így+...

$337 \mathrm{C}$ : lenyomta a fejemet.

338 C: és így izé+...

339 C: követelte.

340C: vagy így letérdeltetett a földön. 